\author{
Aleksandra RUMAK, Danuta KOWALSKA, Agata KOWALEWSKA \\ Air Force Institute of Technology (Instytut Techniczny Wojsk Lotniczych)
}

\title{
PROPERTIES OF DE-ICING AGENTS FOR USE ON PAVED AIRFIELD PAVEMENTS AFTER THEIR EXPIRATION DATES
}

\begin{abstract}
The NO-17-A205:2017 "Airfield maintenance in winter. Use of de-icers. Requirements and tests" Military Standard is applicable at Polish Armed Forces airports in the process of winter maintenance of airport pavements, both in the process of supplying airports with de-icing agents based on acetates and formates, as in testing, acceptance and control of de-icing agents based on formates, acetates and urea. After the expiration date of product, the tests specified in NO-17-A205:2017 shall be repeated.

Purpose of the research is to determine physico-chemical properties changes of de-icing agents applied on artificial airfield pavements, after its expiration dates. The results of research on physical and chemical parameters of de-icing agents obtained at the stage of delivery and after its expiration dates have been given. The tests included determination of appearance, density, refractive index and $\mathrm{pH}$ value measurement, as well as checking the freezing point temperature and, in the case of deicing agents in form of granulate, checking the granules size distribution. The requirements and test methods for deicing agents in accordance with NO-17-A205:2017 are also presented. In case of parameters changes, recommendations regarding further use of these agents shall be made. Positive tests results shall be the basis for extending the shelf life of de-icing products for the next winter season.
\end{abstract}

Keywords: de-icing agents, physico-chemical properties, expiration dates 


\section{Introduction}

Airport pavements shall be in continuous operability over the year, ensuring the safety of aircraft's takeoff and landing. De-icing of airport pavements is necessary in Poland's climatic conditions for several months of the year. The use of chemical de-icing agents resulting from the need to de-ice the surface of airport's functional elements, i.e. runways, may have a destructive effect on airfield pavement. Chemical substances for winter surface maintenance cause corrosion on airfield pavement [7], as well as on operational flying and ground equipment. The concrete's resistance to de-icing agents is one of the parameters determining the durability of concrete during the airfield pavement's operation life. Urea and glycols commonly used so far at airports do not comply with the requirements regarding effectiveness and its negative impact on the environment [14].

De-icing agents commonly used at airports in Poland are the sodium acetate, potassium acetate, sodium formate and potassium formate based. These agents are more de-icing effective and more environmentally friendly (the importance of environment protection issues at airports and their surrounding areas has increased significantly in recent years) than other de-icing products applied on the airfield pavements so far. Nevertheless, signs of premature deterioration of airfield pavement surface (a characteristic pattern of cracks for instance) due to de-icing agents use [15] at airports are observed. It is suspected that agents may cause the acceleration of adverse chemical reactions, as alkali-silica reactions in airport surface concretes [13].

The only one document approved so far in Poland that presents a set of test methods for de-icing agents' evaluation in terms of using them for airfield pavement's de-icing purposes, likewise after the expiration date of de-icing product, is the Military Standard NO-17-A205:2017 Airfield maintenance in winter. Use of de-icers. Requirements and tests [12]. It allows using of acetate and formate based de-icing agents that comply with AMS 1435 [4] and AMS 1431 [3] documents.

The AMS 1435D Fluid, generic, deicing/anti-icing. Runways and taxiways provides information about periodic tests methods and requirements for liquid products used for deicing airports' runways, taxiways, and other aircraft maneuvering areas, in order to prevent and remove frozen deposits of snow, frost, and ice. Product, as received by purchaser, shall be homogeneous, uniform in color, and free from skins, lumps, and foreign materials detrimental to usage of the product. If the product is colored, it shall be blue. In scope of the physical properties, it shall conform to the enclosed requirements of parameters as: flash point, specific gravity, $\mathrm{pH}$, freezing point temperature, effect on aircraft metals, effect o transparent plastics, effect on painted and unpainted surfaces, rinsibility, effect on runway pavements, storage stability, performance and effect on carbon-brake systems.

The AMS 1431E Compound, Solid Runway and Taxiway Deicing/Anti-Icing specification covers a runway deicing and anti-icing product in the form of a solid. The document provides information about tests methods and requirements for solid products used for de-icing the surface of airports' runways, taxiways, and other aircraft maneuvering areas. The product, as received by purchaser, shall be uniform, free-flowing, and free from 
foreign material detrimental to usage of the product. Product shall conform to enclosed requirements of physical parameters tested $(\mathrm{pH}$, flash point, chloride content, storage stability, effect on transparent plastics, effect on painted and unpainted surfaces, effect on runway pavements, effect on aircraft metals, performance and effect on carbon-brake systems.

The manufacturer of liquid or solid runway deicing product shall provide environmental information, including not less than: Biochemical Oxygen Demand (BOD) of the products' solutions incubated at $68^{\circ} \mathrm{F}\left(20^{\circ} \mathrm{C}\right)$ (the percent of product biodegraded in 5 days in case of liquid de-icing agent, the percent of product biodegraded in 5, 15, and 20day incubation periods in case of solid de-icing agent), Total Oxygen Demand (TOD) or Chemical Oxygen Demand (COD) of the product, expressed in kilograms of oxygen per kilograms of product. It shall include trace contaminants information as well (presence in percentage by weight, of sulfur, halogens, phosphate, nitrate, and heavy metals (lead, chromium, cadmium, and mercury). An aquatic toxicity of the products shall be given.

While these specifications cover technical requirements for liquid and solid runway deicing/anti-icing products, specifications do not address the compatibility issue of combining runway deicing products during the operational phase. Products meeting these specifications are unique to each manufacturer and may be adversely affected by combining with other deicing/anti-icing products. It is the user's responsibility to become familiar with the safe and proper use of applying multiple deicing/anti-icing products.

The friction coefficient determination of the runway after the application of deicing/anti-icing product prior to aircraft landing operations shall be held by airport authorities.

Moreover, the types of de-icing substances authorized by the FAA (Federal Aviation Administration) have been specified in the document Advisory Circular 150/5200-30D, Airport Winter Safety and Operations [16]. In addition, chemicals that may have harmful effect on aircraft, airfield pavement or environment shall not be used, in accordance with Annex 14 to the Convention on International Civil Aviation [5].

The approach presented in the article remains insufficiently explored. This paper addresses the need for identification of de-icing agents' properties, after its expiration dates, so far lacking in the scientific literature. Most studies have relied on test methods and verification of de-icing agents properties, and its impact on asphalt $[2,18]$ and cement concrete $[1,17,11]$. A new approach is therefore needed for examination of de-icing agents after its expiration dates, in order to select appropriate products for deicing and extend durability of the airfield pavement. 


\section{NO-17-A205:2017 Military Standard's requirements}

In order to confirm stability of de-icing agent's properties, after its expiration dates, it is necessary to perform repeated tests of physico-chemical properties in accordance with NO-17-A205:2017 Airfield maintenance in winter. Use of de-icers. Requirements and tests Military Standard, as when accepting a new delivery, and compare the values obtained with the declared values for a specific product lot. Requirements for checking de-icing agents at delivery stage are also included in the Instructions of the Chief of Inspectorate for Armed Forces Support, dated February 6, 2015 [9] regarding verification of de-icing agents for pavement winter maintenance supplied to military airports.

In accordance with above mentioned documents, it is required to use de-icing agents that complies with following criteria:

- appearance,

Liquid de-icing agents seen with the unaided eye shall be a clear, homogeneous solution, uniform in color, with no scum, sediments, suspensions or other visible impurities that could unfavourably affect the agents' performance (impeding the use of the product).

Solid de-icing agents, seen with the unaided eye, shall be granules of uniform color, with no flow marks (bulk material), visible impurities and foreign objects that could unfavourably affect the agents' performance (impeding the use of the product).

It is recommended that the solid deicer (in form of granules) shall have a form of an irregular granule, providing the best conditions for moisture absorption, after the granulate had been spilled over the surface, minimizing the risk of blowing granulate off the runway edge due to the wind or aircraft's engine blast.

Granules size distribution recommended (in accordance with NO-17-A205:2017 Military Standard [12]):

- percentage of mass retained, that passed the $4 \mathrm{~mm}$ size test sieve and remained on $1 \mathrm{~mm}$ size test sieve: $\geq 85 \%$.

- density,

Each liquid and solid (15\% water solution by weight) product's lot density value in $20^{\circ} \mathrm{C}$ temperature shall be declared by a Supplier. Meanwhile, the value of each analyzed sample's density shall not differ by $\pm 0,015$ from the declared value.

- refractive index,

Refractive index value in $20^{\circ} \mathrm{C}$ temperature of each liquid and solid (15\% water solution by weight) product's lot shall be declared by a Supplier. Meanwhile, the value of each analyzed sample's refractive index shall not differ by $\pm 0,003$ from the declared value.

- $\mathrm{pH}$,

$\mathrm{pH}$ value at $20^{\circ} \mathrm{C}$ temperature of each liquid product's lot shall be declared by a Supplier. Meanwhile, the value of each analyzed sample's $\mathrm{pH}$ value shall fall within 7,0 $\leq \mathrm{pH} \leq 11,5$ range and $\mathrm{pH}$ value of 1:1 diluted solutions shall be not lower than 6 . The value of each analyzed sample's $\mathrm{pH}$ value shall not differ by $\pm 0,5$ from the declared value. 
$\mathrm{pH}$ value in $20^{\circ} \mathrm{C}$ temperature of each solid product's lot (15\% water solution by weight) shall be declared by a Supplier. Meanwhile, the value of each analyzed sample's pH value shall not differ by $\pm 0,5$ from the declared value.

- freezing temperature (crystallization),

The accuracy of delivered product's concentration is determined on the basis of information provided by a Supplier. The freezing point of liquid de-icing agent's 1:1 solution (by weight) shall not be higher than $(-14.5)^{\circ} \mathrm{C}$.

The freezing point of the $15 \%$ aqueous solution (by weight) prepared from a batch of solid product shall not be higher than $(-7,0)^{\circ} \mathrm{C}$.

Positive results of control tests carried out on all taken samples, after its expiration dates, are the basis for extending the expiry date for the next winter season.

\section{Experimental section}

\subsection{De-icing agents tested}

In order to indicate changes of physico-chemical properties, between properties of deicing agents at delivery stage and after expiration date, the following samples of de-icing agents have been analyzed (tab. 1).

Table 1

Summary of analyzed de-icing agents

\begin{tabular}{|c|c|c|c|c|c|}
\hline $\begin{array}{c}\text { Form of } \\
\text { de-icing } \\
\text { agent }\end{array}$ & $\begin{array}{c}\text { Main } \\
\text { compound }\end{array}$ & $\begin{array}{c}\text { Manufacturer/ } \\
\text { Supplier }\end{array}$ & $\begin{array}{l}\text { Additional } \\
\text { marking }\end{array}$ & $\begin{array}{l}\text { Production } \\
\text { date }\end{array}$ & $\begin{array}{c}\text { Expiration } \\
\text { date }\end{array}$ \\
\hline \multirow{3}{*}{ Liquid } & \multirow{3}{*}{$\begin{array}{l}\text { Potassium } \\
\text { formate }\end{array}$} & $\mathrm{A}$ & liquid No. 1 & \multirow{6}{*}{2015} & \multirow{6}{*}{$\begin{array}{l}2 \text { years from } \\
\text { production } \\
\text { date }-2017\end{array}$} \\
\hline & & $\mathrm{B}$ & liquid No. 2 & & \\
\hline & & $\mathrm{B}$ & liquid No. 3 & & \\
\hline \multirow{3}{*}{$\begin{array}{l}\text { Solid } \\
\text { (granules) }\end{array}$} & \multirow{3}{*}{$\begin{array}{l}\text { Sodium } \\
\text { formate }\end{array}$} & B & granulate No.1 & & \\
\hline & & B & granulate No. 2 & & \\
\hline & & B & granulate No. 3 & & \\
\hline
\end{tabular}

Samples of liquid de-icing agents were supplied by two manufacturers/suppliers, while the samples of solid de-icing agents were of the same manufacturer/supplier (due to the lack of data collected at delivery stage) but of different batches.

All the above mentioned liquid de-icing agents complies with requirements of AMS 1435 [4] specification, whereas the de-icing agents in form of granulate complies with AMS 1431 [3] specification's requirements. 
The characteristics of analyzed de-icing agents are summarized below on the basis of information data provided by the suppliers. Overview of parameters regarding liquid deicing agents' properties are presented in tab. 2, parameters of solid (granulate) de-icing agents' properties are presented in tab. 3 .

Table 2

\section{Properties of liquid de-icing agents declared by suppliers}

\begin{tabular}{|c|c|c|c|c|}
\hline \multirow[t]{2}{*}{ No. } & \multirow{2}{*}{ Property } & \multicolumn{3}{|c|}{ Values declared by Supplier } \\
\hline & & liquid No. 1 & liquid No. 2 & liquid No. 3 \\
\hline \multirow[t]{2}{*}{1} & Appearance & \multicolumn{3}{|c|}{ Clear, transparent liquid } \\
\hline & Freezing point, ${ }^{\circ} \mathrm{C}$ & \multicolumn{3}{|l|}{-60} \\
\hline 2 & $\begin{array}{l}\text { Freezing point - fluid diluted } \\
1: 1,{ }^{\circ} \mathrm{C}\end{array}$ & \multicolumn{3}{|l|}{$-14,5$} \\
\hline 3 & $\begin{array}{l}\text { Concentration of potassium } \\
\text { formate, } \% \text { by weight }\end{array}$ & \multicolumn{3}{|l|}{$\sim 50 \%$} \\
\hline 4 & $\mathrm{pH}, 20^{\circ} \mathrm{C}$ & 10.2 & 10.7 & 10.8 \\
\hline 5 & Density, $\mathrm{g} / \mathrm{cm}^{3}$ & \multicolumn{3}{|l|}{1.34} \\
\hline 6 & Refractive index & N/D & N/D & N/D \\
\hline 7 & $\begin{array}{l}\text { Chemical Oxygen Demand } \\
\text { (COD), } \mathrm{kg} \mathrm{O}_{2} / \mathrm{kg}\end{array}$ & \multicolumn{3}{|l|}{0,11} \\
\hline 8 & $\begin{array}{l}\text { Biological Oxygen Demand } \\
\text { (BOD5), } \mathrm{kg} \mathrm{O}_{2} / \mathrm{kg}\end{array}$ & \multicolumn{3}{|l|}{0,04} \\
\hline
\end{tabular}

Table 3

\section{Properties of solid de-icing agents declared by suppliers}

\begin{tabular}{|c|c|c|c|c|}
\hline \multirow[t]{2}{*}{ No. } & \multirow[t]{2}{*}{ Property } & \multicolumn{3}{|c|}{ Values declared by Supplier } \\
\hline & & granulate No. 1 & granulate No. 2 & granulate No. 3 \\
\hline 1 & Appearance & $\begin{array}{l}\text { White, irregular } \\
\text { granules }\end{array}$ & $\begin{array}{l}\text { White, irregular } \\
\text { granules }\end{array}$ & $\begin{array}{l}\text { White, irregular } \\
\text { granules }\end{array}$ \\
\hline 2 & Particle size, $\mathrm{mm}$ & $2-4 \mathrm{~mm}$ & $\mathrm{~N} / \mathrm{D}$ & $\mathrm{N} / \mathrm{D}$ \\
\hline 3 & $\begin{array}{l}\text { Freezing temperature }(15 \% \\
\text { solution by weight), }{ }^{\circ} \mathrm{C}\end{array}$ & -8.3 & -9.0 & \\
\hline 4 & $\begin{array}{l}\text { Concentration of sodium formate, } \\
\% \text { by weight }\end{array}$ & 98,5 & $98 \pm 1$ & \\
\hline 5 & Water content, $\%$ by weight. & $\leq 1$ & $1.6 \div 1.8$ & \\
\hline 6 & Chlorides content, $\mathrm{ppm}$ & $\mathrm{N} / \mathrm{D}$ & $125 \div 250$ & \\
\hline 7 & $\mathrm{pH}, 20^{\circ} \mathrm{C}(15 \%$ solution by weight $)$ & $8-11$ & $11.53 \div 11.88$ & \\
\hline 8 & $\begin{array}{l}\text { Density, } \mathrm{g} / \mathrm{cm}^{3}(15 \% \text { solution } \\
\text { by weight) }\end{array}$ & $\mathrm{N} / \mathrm{D}$ & 1.09306 & \\
\hline 9 & $\begin{array}{l}\text { Refractive index (15\% solution by } \\
\text { weight) }\end{array}$ & N/D & 1,35196 & \\
\hline 10 & Bulk density, $\mathrm{kg} / \mathrm{m}^{3}$ & $900-950$ & N/D & N/D \\
\hline 11 & Temperature of decomposition, ${ }^{\circ} \mathrm{C}$ & N/D & $<250$ & \\
\hline
\end{tabular}




\begin{tabular}{|l|l|l|l||}
\hline 12 & $\begin{array}{l}\text { Chemical Oxygen Demand (COD), } \\
\mathrm{kg} \mathrm{O}_{2} / \mathrm{kg}\end{array}$ & 0.34 & 0.27 \\
\hline 13 & $\begin{array}{l}\text { Biological Oxygen Demand } \\
\left(\mathrm{BOD}_{5}\right), \mathrm{kg} \mathrm{O} / \mathrm{kg}\end{array}$ & 0.02 & 0.14 \\
\hline
\end{tabular}

The basic component of liquid deicing agents is potassium formate. Aqueous solutions of concentration about $50 \%$ by weight contain corrosion inhibitors. The basic constituent of solid deicing agents is sodium formate. Solid de-icing agents contain about $98 \%$ of the main ingredient and are additionally enriched with a corrosion inhibitor.

\subsection{Test results}

The results of physico-chemical properties of de-icing agents applied on artificial airfield pavements, obtained at the stage of delivery and after its expiration dates are presented. The tests included determination of appearance, density, refractive index and $\mathrm{pH}$ value measurement, as well as checking the freezing point temperature and, in the case of de-icing agents in form of granulate, checking the granules size distribution. Results of tested de-icing agents are compiled with declared values of parameters by suppliers.

\subsubsection{Appearance, density, refractive index, ph results}

No changes in appearance of analyzed samples at the stage of delivery and after expiration dates were observed.

De-icing agents in form of liquid (samples: liquid No. 1, liquid No. 2, liquid No. 3 ) are clear, transparent without sediments and suspensions.

Solid samples of de-icing agents (samples: granulate No. 1, granulate No. 2 and granulate No. 3) are in form of white granules (irregular particles size). Granulate is free flowing, without impurities or foreign matters.

Density and refractive index measurements were performed on liquid and, in case of granulate, water solutions ( $15 \%$ by weight). Solutions were prepared with the use of Pionier balance, Ohaus. Densimeter DMA 500, refractometer Abbemat 300 manufactured by Anton Paar, and HI 98191 pH meter of Hanna Instruments were used.

Measurements results of liquid de-icers samples are presented in tab. 4, and solid deicers in tab. 5 . 
Table 4

Mean values of liquid de-icing agents' physico-mechanical properties at the stage of delivery and after expiration dates

\begin{tabular}{|c|c|c|c|c|c|c|c|c|c|}
\hline \multirow[b]{2}{*}{ Sample No. } & \multicolumn{3}{|c|}{ Density, $20^{\circ} \mathrm{C}\left[\mathrm{g} / \mathrm{cm}^{3}\right]$} & \multicolumn{3}{|c|}{ Refractive index, $20^{\circ} \mathrm{C}$} & \multicolumn{3}{|c|}{$\mathrm{pH}$} \\
\hline & $\begin{array}{c}\text { at the } \\
\text { stage of } \\
\text { delivery }\end{array}$ & $\begin{array}{c}\text { after } \\
\text { expiratio } \\
\text { n date }\end{array}$ & $\begin{array}{c}\text { value } \\
\text { declared } \\
\text { by a } \\
\text { Supplier }\end{array}$ & $\begin{array}{c}\text { at the } \\
\text { stage of } \\
\text { delivery }\end{array}$ & $\begin{array}{c}\text { after } \\
\text { expirati } \\
\text { on date }\end{array}$ & $\begin{array}{c}\text { value } \\
\text { declar } \\
\text { ed by } \\
\text { a } \\
\text { Suppli } \\
\text { er }\end{array}$ & $\begin{array}{l}\text { at the } \\
\text { stage of } \\
\text { delivery }\end{array}$ & $\begin{array}{c}\text { after } \\
\text { expira } \\
\text { tion } \\
\text { date }\end{array}$ & $\begin{array}{c}\text { value } \\
\text { declare } \\
\text { d by a } \\
\text { Suppli } \\
\text { er }\end{array}$ \\
\hline liquid No. I & 1.3419 & 1.3416 & \multirow{3}{*}{1.34} & 1.38802 & 1.38803 & \multirow{3}{*}{ N/D } & 10.28 & 9.75 & 10.2 \\
\hline liquid No. 2 & 1.3363 & 1.3399 & & 1.3878 & 1.38771 & & 10.32 & 10.02 & 10.7 \\
\hline liquid No. 3 & 1.3409 & 1.3399 & & 1.3880 & 1.38771 & & 10.45 & 10.00 & 10.8 \\
\hline $\begin{array}{l}\text { Permissible } \\
\text { deviations from } \\
\text { declared values } \\
\text { in accordance } \\
\text { with NO-17- } \\
\text { A205:2017 }\end{array}$ & \pm 0.015 & & & \pm 0.003 & & & \pm 0.5 & & \\
\hline
\end{tabular}

Table 5

\section{Mean values of solid de-icing agents' physico-mechanical properties at the stage} of delivery and after expiration dates

\begin{tabular}{|c|c|c|c|c|c|c|c|c|c|}
\hline \multirow[b]{2}{*}{ Sample No. } & \multicolumn{3}{|c|}{ Density, $20^{\circ} \mathrm{C}\left[\mathrm{g} / \mathrm{cm}^{3}\right]$} & \multicolumn{3}{|c|}{ Refractive index, $20^{\circ} \mathrm{C}$} & \multicolumn{3}{|c|}{$\overline{\mathrm{pH}}$} \\
\hline & $\begin{array}{l}\text { at the } \\
\text { stage } \\
\text { of } \\
\text { deliver } \\
y\end{array}$ & $\begin{array}{c}\text { after } \\
\text { expirat } \\
\text { ion } \\
\text { date }\end{array}$ & $\begin{array}{c}\text { value } \\
\text { declared } \\
\text { by a } \\
\text { Supplier }\end{array}$ & $\begin{array}{c}\text { at the } \\
\text { stage of } \\
\text { delivery }\end{array}$ & $\begin{array}{c}\text { after } \\
\text { expirati } \\
\text { on date }\end{array}$ & $\begin{array}{c}\text { value } \\
\text { declared } \\
\text { by a } \\
\text { Supplier }\end{array}$ & $\begin{array}{l}\text { at the } \\
\text { stage } \\
\text { of } \\
\text { delive } \\
\text { ry }\end{array}$ & $\begin{array}{l}\text { after } \\
\text { expira } \\
\text { tion } \\
\text { date }\end{array}$ & $\begin{array}{c}\text { value } \\
\text { declare } \\
\text { d by a } \\
\text { Suppli } \\
\text { er }\end{array}$ \\
\hline granulate No. I & 1.0951 & 1.0949 & N/D & 1.35201 & 1.35201 & N/D & 10.44 & 10.45 & $8-11$ \\
\hline granulate No. 2 & 1.0929 & 1.0922 & \multirow{2}{*}{1.09306} & 1.35191 & 1.35173 & \multirow{2}{*}{1.35196} & 11.45 & 10.38 & $\begin{array}{l}11.53 \\
\div \\
11.88\end{array}$ \\
\hline granulate No. 3 & 1.0901 & 1.0904 & & 1.35201 & 1.35168 & & 11.88 & 10.95 & $\begin{array}{l}11.53 \\
\div \\
11.88\end{array}$ \\
\hline $\begin{array}{l}\text { Permissible } \\
\text { deviations from } \\
\text { declared values in } \\
\text { accordance } \\
\text { with NO-17- } \\
\text { A205:2017 }\end{array}$ & \multicolumn{3}{|l|}{ \pm 0.015} & \multicolumn{3}{|l|}{ \pm 0.003} & \multicolumn{3}{|l|}{ \pm 0.5} \\
\hline
\end{tabular}

The greatest changes in physico-chemical properties were observed in case of $\mathrm{pH}$ values. The $9 \%$ and $8 \%$ decreases of $\mathrm{pH}$ values, in reference to values obtained at the stage of delivery were observed in case of granulate No. 2 and granulate No. 3 samples respectively, whereas in case of samples of liquid de-icing agents: liquid No. 1, liquid 
No. 2 and liquid No. 3, the pH value decreased by 5\%, 3\% and $4 \%$ respectively. Despite these $\mathrm{pH}$ values decreases, only liquid No. 1 and granulate No. 1 samples fulfill the requirements regarding permissible deviations from declared values in accordance with NO-17-A205:2017 standard. Sample of granulate No. 1 best maintained the physicomechanical properties, including density, refractive index and $\mathrm{pH}$ values that complies with requirements of permissible deviations from values declared by suppliers.

\subsubsection{Results of granules size distribution of analyzed de-icing agents}

The analysis of granules size distribution was conducted in accordance with NO-17A205:2017 Airfield maintenance in winter. Use of de-icers. Requirements and tests [12] Military Standard. Samples of analyzed granulates were sieved with use of test sieves with $6 \mathrm{~mm}, 5 \mathrm{~mm}, 4 \mathrm{~mm}, 3 \mathrm{~mm}, 2 \mathrm{~mm}, 1 \mathrm{~mm}$ and $0.5 \mathrm{~mm}$ apertures. Weight measurements were performed with Pionier PA $413 \mathrm{C} / 1$ of Ohaus balance. Cumulative percentages passing the test sieves is presented in tab. 6 and illustrated in figs. $1 \div 3$. The percentage of granules retained is presented in tab. 7 .

Table 6

Mean test results of granulate sieve analysis of samples: granulate No. 1, granulate No. 2 and granulate No. 3 (cumulative mass passing the test sieve with specific aperture [\%])

\begin{tabular}{|c|c|c|c|c|c|c|}
\hline \multirow{3}{*}{$\begin{array}{l}\text { Test sieve aperture size } \\
{[\mathrm{mm}]}\end{array}$} & \multicolumn{2}{|c|}{ granulate No. 1} & \multicolumn{2}{|c|}{ granulate No. 2} & \multicolumn{2}{|c|}{ granulate No. 3} \\
\hline & \multicolumn{6}{|c|}{ Cumulative passing [\%] } \\
\hline & $\begin{array}{l}\text { at delivery } \\
\text { stage }\end{array}$ & $\begin{array}{c}\text { after } \\
\text { expiration } \\
\text { date }\end{array}$ & $\begin{array}{l}\text { at delivery } \\
\text { stage }\end{array}$ & $\begin{array}{c}\text { after } \\
\text { expiration } \\
\text { date }\end{array}$ & $\begin{array}{l}\text { at delivery } \\
\text { stage }\end{array}$ & $\begin{array}{c}\text { after } \\
\text { expiration } \\
\text { date }\end{array}$ \\
\hline 6.0 & 100.0 & 100.0 & $\mathrm{~N} / \mathrm{D}$ & 99.8 & $\mathrm{~N} / \mathrm{D}$ & 99.9 \\
\hline 5.0 & 100.0 & 100.0 & 96.2 & 91.3 & 96.2 & 97.8 \\
\hline 4.0 & 99.9 & 99.9 & 73.5 & 63.2 & 73.5 & 84.1 \\
\hline 3.0 & 81.8 & 88.0 & N/D & 41.9 & N/D & 57.0 \\
\hline 2.0 & 13.5 & 11.6 & 2.6 & 5.8 & 2.6 & 8.3 \\
\hline 1.0 & 3.5 & 1.0 & 0.3 & 0.8 & 0.3 & 0.7 \\
\hline 0.5 & 2.1 & 0.7 & 0.2 & 0.5 & 0.2 & 0.4 \\
\hline$<0.5$ & 0.0 & 0.0 & 0.0 & 0.0 & 0.0 & 0.0 \\
\hline
\end{tabular}




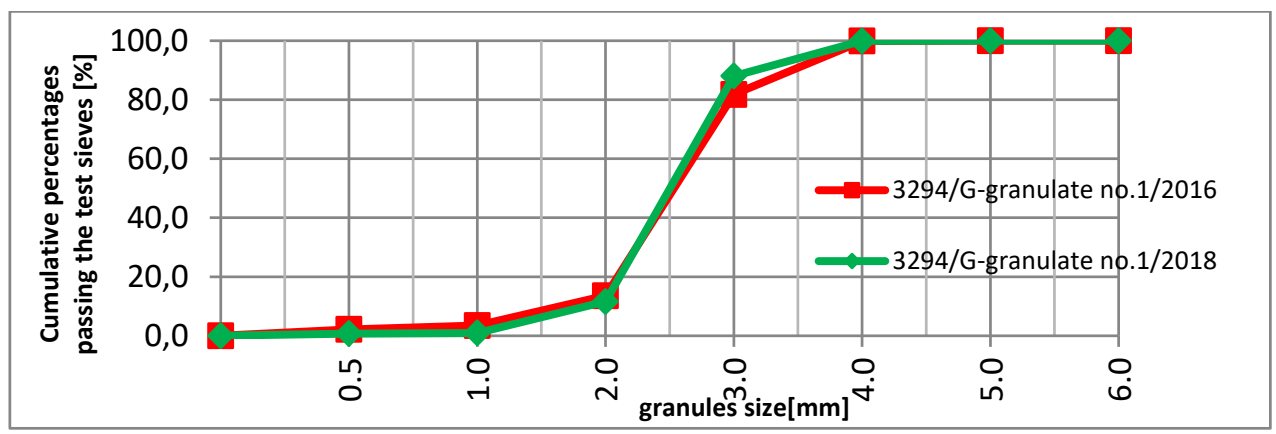

Fig. 1. Cumulative percentages passing the test sieves of granulate No. 1 at the stage of delivery in 2016 and after its' expiration date in year 2018

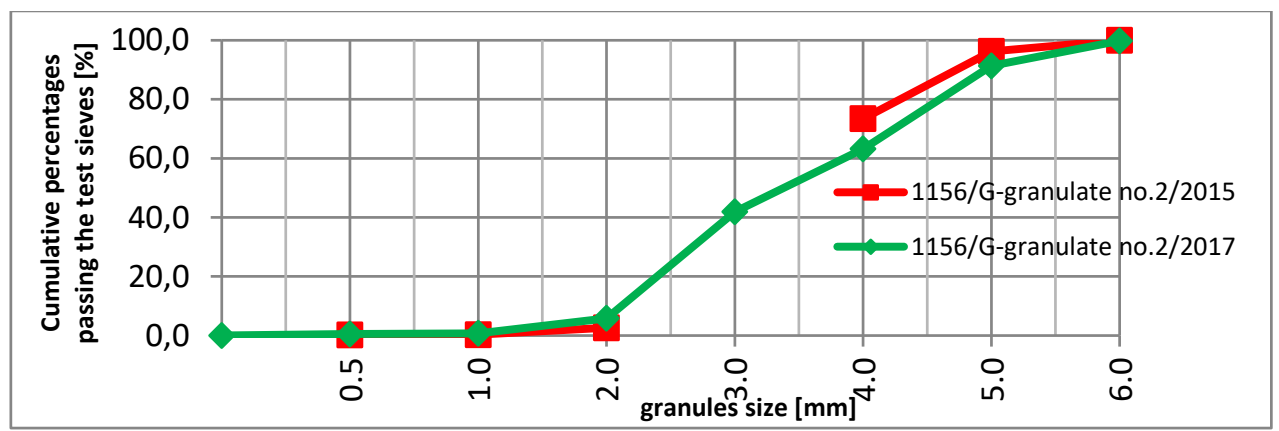

Fig. 2. Cumulative percentages passing the test sieves of granulate No. 2 at the stage of delivery in 2015 and after its' expiration date in year 2017

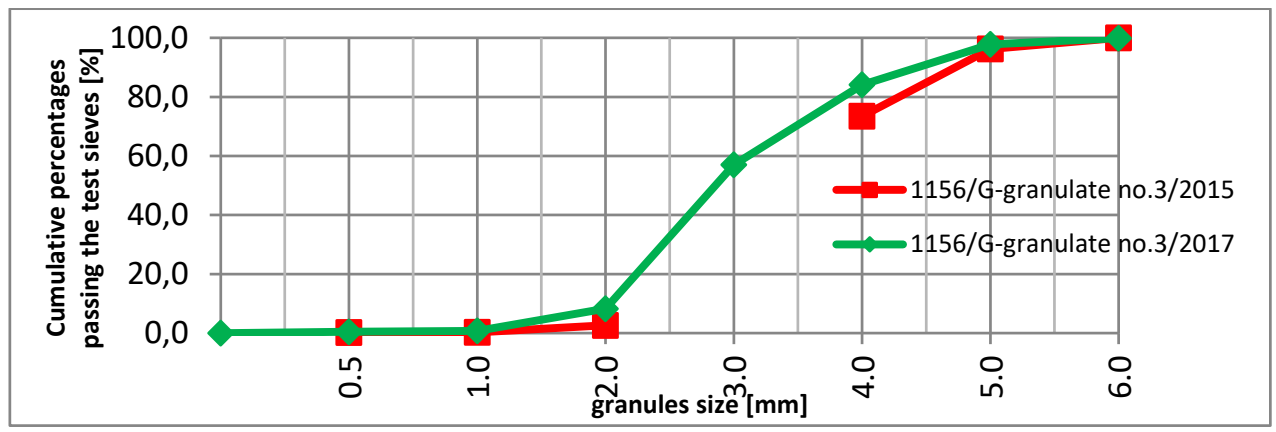

Fig. 3. Cumulative percentages passing the test sieves of granulate No. 3 at the stage of delivery in 2015 and after its' expiration date in year 2017

According to the tab. 6 and graphs $1 \div 3$, granulate No. 1 proves the slightest changes in granules distribution between granulate contents at the delivery stage and after expiration date. 
Table 7

The percentage of granulate retained on test sieves

\begin{tabular}{|c|c|c|c|c|c|c|}
\hline \multirow[b]{3}{*}{$\begin{array}{c}\text { Granules size } \\
{[\mathrm{mm}]}\end{array}$} & \multicolumn{2}{|c|}{ granulate No. 1} & \multicolumn{2}{|c|}{ granulate No. 2} & \multicolumn{2}{|c|}{ granulate No. 3} \\
\hline & \multicolumn{6}{|c|}{ Mass retained on particular test sieves, [\%] } \\
\hline & $\begin{array}{c}\text { at delivery } \\
\text { stage }\end{array}$ & $\begin{array}{c}\text { after } \\
\text { expiration } \\
\text { date }\end{array}$ & $\begin{array}{l}\text { at delivery } \\
\text { stage }\end{array}$ & $\begin{array}{c}\text { after } \\
\text { expiration } \\
\text { date }\end{array}$ & $\begin{array}{c}\text { at delivery } \\
\text { stage }\end{array}$ & $\begin{array}{c}\text { after } \\
\text { expiration } \\
\text { date }\end{array}$ \\
\hline $1.0 \div 2.0$ & 13 & 11 & 2 & 5 & 2 & 8 \\
\hline $2.0 \div 3.0$ & 70 & 76 & N/D & 36 & $\mathrm{~N} / \mathrm{D}$ & 49 \\
\hline $3.0 \div 4.0$ & 14 & 12 & N/D & 21 & N/D & 27 \\
\hline $1.0 \div 4.0$ & 98 & 99 & 73 & 62 & 73 & 83 \\
\hline
\end{tabular}

In accordance with NO-17-A205:2017 Military Standard, the recommended percentage of mass passing the $4 \mathrm{~mm}$ test sieve and remaining on $1 \mathrm{~mm}$ test sieve is $\geq 85 \%$. Granulates No. 2 and 3 have not complied with standard's recommendations regarding granulation neither after expiration date nor at the delivery stage.

Due to the partial lack of data regarding granulates masses remaining on $3 \mathrm{~mm}$ test sieve, the percentages of mass retained on $1 \div 4 \mathrm{~mm}$ test sieves at the delivery stage and after expiration date are compared. The granulate No. 1 proves to be the most stable, with difference of $1 \%$. In the cases of granulate No. 2 and No. 3, these differences are greater $11 \%$ and $10 \%$ respectively.

\subsubsection{Freezing point temperature determination}

Freezing point temperatures have been determined with the use of active surface condition sensor IT-Arctis (also called Arctis type IT). It allows accurate, active measurement of freezing point temperature. The sensor uses the so-called Peltier cell (also known as TEC - thermoelectric cooler) for heating and cooling its surface to simulate coming of frost. Independent of the composition of the liquid, it allows accurate measurement of the freezing point temperature by cooling itself down to a temperature, lower (e.g. by $15^{\circ} \mathrm{C}$ ) than the surface temperature. The IT-Arctis sensor runs measurement cycles below the surface temperature of $4^{\circ} \mathrm{C}$ and in wet conditions in accordance with EN 15518-3:2011 [8] standard.

The sensor is mounted in a block made of cement concrete, in accordance with CEN / TS 15518-4:2013 [6] technical specification. Freezing temperature measurements were made using the WKL 100/70 climate chamber manufactured by Weiss Umwelttechnik $\mathrm{GmbH}$ with a concrete block and sensor inside. The temperature and humidity in the climate chamber were controlled during the test by the LAB-EL thermohygrometer LB-701. Evaporation of water from the solution has been limited during the tests in the chamber (with use of watch glass). Measurements were made with a $60 \mu$ l solutions applied to the 
surface of the sensor. The automatic pipette with a range of 10-100 $\mu$, VWR International bvba was used to apply solutions. The view of the climate chamber with the concrete block inside and apparatus are shown in fig. 4.

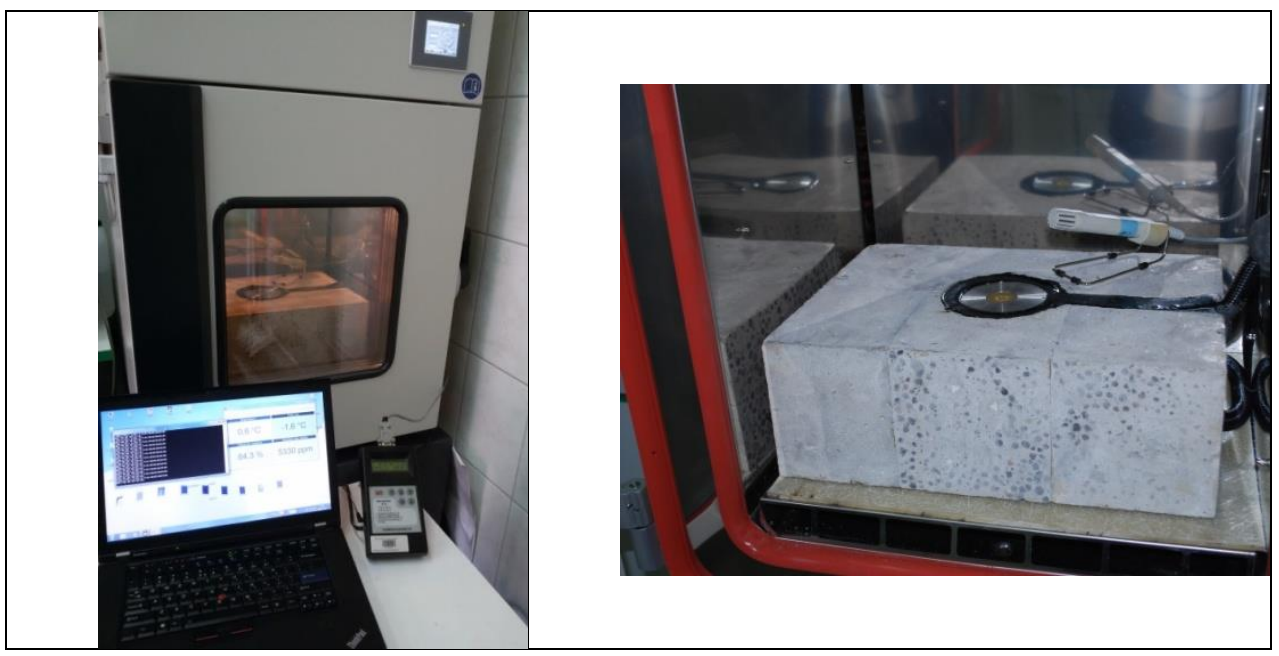

Fig. 4. Climate chamber with the concrete block inside and apparatus used for freezing temperature measurement

Solutions for freezing temperatures measurement were prepared by weight from analyzed de-icing agents. Liquid de-icers based on potassium formate were $50 \%$ diluted with water, whereas $15 \%$ solutions were prepared from solid de-icer (in form of granules, based on sodium formate). Manufacturers of the above mentioned de-icing agents provided the results of determining the freezing points of deicers solutions (tabs. 2 and 3).

Solutions were prepared (by weight, using redistilled water) with the use of Pionier PA balance, Ohaus. Each solution of liquid de-icing agent was measured at $0^{\circ} \mathrm{C}$ temperature, whereas measurement of each $15 \%$ solution of solid de-icing agents was taken at $-10^{\circ} \mathrm{C}$ temperature.

Freezing temperature measurements were recorded automatically every $30 \mathrm{sec}$ using the Freezing Temperature Test (FTT) version 01 software developed by ITWL. Start of the freezing temperature registration was 6 minutes after the application or when the first value in the required tolerance was reported by the sensor, according to CEN/TS 15518-4:2013. Registration of the freezing temperature has been maintained for at least 30 minutes. The accuracy of the freezing temperatures measured in the range of $0^{\circ} \mathrm{C}$ to $-15^{\circ} \mathrm{C}$ is $\pm 0.5^{\circ} \mathrm{C}$, and within the range of $-15^{\circ} \mathrm{C}$ to $-30^{\circ} \mathrm{C}$ it is $\pm 1,5^{\circ} \mathrm{C}$ in accordance with the requirements of $\mathrm{EN}$ 15518-3: 2011.

Freezing point temperatures of the prepared solutions after expiration dates are presented with declared values in tab. 8 . 
Table 8

Freezing temperatures of the analyzed de-icing agents after expiration dates

\begin{tabular}{|c|c|c|c|c|c|}
\hline \multirow{2}{*}{ Lp. } & \multirow{2}{*}{ Main compound } & \multirow{2}{*}{$\begin{array}{c}\text { Testing temperature } \\
{\left[{ }^{\circ} \mathrm{C}\right]}\end{array}$} & \multirow{2}{*}{ Sample No. } & \multicolumn{2}{|c|}{$\begin{array}{l}\text { Freezing point } \\
\text { temperature, }\left[{ }^{\circ} \mathrm{C}\right]\end{array}$} \\
\hline & & & & declared & result \\
\hline 1 & \multirow{3}{*}{ Potassium formate } & \multirow{3}{*}{-15.0} & liquid No. 1 & \multirow{3}{*}{-14.5} & -14.7 \\
\hline 2 & & & liquid No. 2 & & -14.4 \\
\hline 3 & & & liquid No. 3 & & -14.2 \\
\hline 4 & \multirow{3}{*}{ Sodium formate } & \multirow{3}{*}{0.0} & granulate No. 1 & -8.3 & -9.2 \\
\hline 5 & & & granulate No. 2 & \multirow{2}{*}{-9.0} & -8.6 \\
\hline 6 & & & granulate No. 3 & & -8.7 \\
\hline
\end{tabular}

In accordance with NO-17-A205:2017 Military Standard, the freezing point of liquid de-icing agent's 1:1 solution (by weight) shall not be higher than $(-14.5)^{\circ} \mathrm{C}$, whereas the freezing point of the $15 \%$ aqueous solution (by weight) prepared from a batch of solid product shall not be higher than $(-7.0)^{\circ} \mathrm{C}$. All the solid analyzed agents (in form of $15 \%$ solutions by weight) and one sample of liquid de-icer (liquid No. 1) fulfill the afore mentioned requirements, while both samples of liquid No. 2 and 3 do not.

In relation to freezing point temperature values declared by suppliers, only samples of liquid No. 1 and granulate No. 1 meet the suppliers requirements.

\section{Conclusions}

Each deicing agent has a negative impact on the durability of airport pavements and, consequently, on the safety of flight operations $[15,10]$. On the basis of performed tests it has been proved that physico-chemical properties of de-icing agents applied on artificial airfield pavements change during its use time. The requirements and test methods for deicing agents in accordance with NO-17-A205:2017 were presented. Tests involved physico-chemical parameters determination, including appearance, density, refractive index, $\mathrm{pH}$ value, freezing point temperature and, in case of de-icing agents in form of granulate, the granules size distribution. Granulate No. 1 proved to have the most stable physicochemical properties, in reference to density, refractive index, $\mathrm{pH}$ value, as well as the freezing point temperature and granules size distribution. Granulate No. 2 and No. 3 do not fulfill the requirements regarding permissible deviations from declared values in accordance with NO-17-A205:2017 standard of pH values after products' expiration dates. In case of liquid samples, all three samples (liquid No. 1, liquid No. 2 and liquid No. 3) proved significant decreases of $\mathrm{pH}$ values, and thus not complying with values declared by 
suppliers (only sample of liquid 1 complies with NO-17-A205:2017 standard's requirements with permissible deviations considered).

Due to the parameters changes, recommendations regarding further use of these agents shall be made. Recommendations may involve the intended pavement type for the de-icers use (runway, taxiways, aprons, technical roads at airport). The age of pavements, on which the de-icing agents will be used, shall be considered in accordance with NO-17-A205:2017 requirements. It may be recommended to use up the de-icing agents in the upcoming winter season. In case of not having used up the agents, it shall be recommended to utilize the above-mentioned agents.

Due to significant changes in physico-mechanical properties of de-icing agents, presented in the article there is a need to constantly determine impact of de-icing agents on airfield pavements. It will allow for adequate protection and selection of appropriate products for deicing, as well as extending durability of the airfield pavement. This problem is especially important in terms of use on airport's airfield pavements up to three years since it has been built.

\section{References}

1. American Concrete Institute: Guide to Durable Concrete. ACI 201-16. American Concrete Institute, Farmington Hills, 2016.

2. Anastasio S., Nilsen K.: Measuring the effect of de-icing solutions on the adhesion of asphalt mixtures. ECTRI -FEHRL -FERSI Young Researchers Seminar, Rome, Italy, 2015.

3. AMS 1431E Compound, Solid Runway and Taxiway Deicing/Anti-Icing.

4. AMS 1435D Fluid, generic, deicing/anti-icing. Runways and taxiways.

5. Annex 14 to the Convention on International Civil Aviation, 2018. Aerodromes. Volume I - Aerodrome Design and Operations. Eight Edition.

6. CEN/TS 15518-4:2013 Winter maintenance equipment - Road weather information system - Part 4: Test methods for stationary equipment.

7. Christensen D. et al.: Effect of De-icing and Anti-icing Chemicals on HMA Airfield Runaways. FAA Worldwide Airport Technology Transfer Conference, Atlantic City, N.J., 2010.

8. EN 15518-3: 2011 Winter maintenance equipment - Road weather information systems - Part 3: Requirements on measured values of stationary equipments.

9. Instructions of the Chief of Inspectorate for Armed Forces Support regarding control of the de-icing agents for winter maintenance of pavements supplied to military airports. February 6, 2015.

10. Kowalska D., Pietruszewski P.: Deicer effects to airfield pavement cement concrete. Monographs of cement concrete technology, Cracow 2016. 
11. Kowalska D., Rumak A.: Durability of airfield pavement cement concrete in the presence of de-icing agents. Journal of Konbin, Vol. 48, 2018, DOI 10.2478/jok-20180046.

12. NO-17-A205:2017 Airfield maintenance in winter. Use of de-icers. Requirements and tests.

13. Pan T., He X., Shi X.: Laboratory Investigation of Acetate-Based Deicing/Anti-icing Agents Deteriorating Airfield Asphalt Concrete. 83rd Annual Meeting of the Association of Asphalt Paving Technologist (AAPT), Philadelphia 2008.

14. Reeves S.J., Evans M.G., Burtwell M.: Evaluation of Frost, Ice and Snow Precautions at Stations: Rail Safety and Standards Board. Project T532, Transport Research Laboratory, London 2005.

15. Shi X.: Impact of Airport Pavement De-icing Products on Aircraft and Airfield Infrastructure. A CRP Synthesis 6, Airport Cooperative Research Program, Transportation Research Board, Washington 2008.

16. U.S. Department of Transportation, Federal Aviation Administration, 2016. Advisory Circular No. 150 / 5200-30D Airport Field Condition Assessments and Winter Operations Safety.

17. Van Dam T.: Tech Brief: Chemical deicers and concrete pavement: Impacts and mitigation. FHWA-HIF-17-008. Federal Highway Administration, Washington, DC 2016.

18. Widyatmoko D., Dehdezi P.: De-icing/Anti-icing agents and their effects on airfield asphalt pavements. Asphalt Professional, 2015. 